\title{
Micropropagation, antinociceptive and antioxidant activities of extracts of Verbena litoralis Kunth (Verbenaceae)
}

\author{
VIRGÍNIA F. BRAGA ${ }^{1}$, GISELLE C. MENDES ${ }^{1}$, RAPHAEL T.R. OLIVEIRA ${ }^{1}$, CARLA Q.G. SOARES ${ }^{1}$, \\ CRISTIANO F. RESENDE ${ }^{1}$, LEANDRO C. PINTO ${ }^{2}$, REINALDO DE SANTANA ${ }^{2}$, LYDERSON F. VICCINI ${ }^{3}$, \\ NÁDIA R.B. RAPOSO ${ }^{2}$ AND PAULO H.P. PEIXOTO ${ }^{1}$ \\ ${ }^{1}$ Instituto de Ciências Biológicas, Departamento de Botânica, Laboratório de Fisiologia Vegetal, \\ Universidade Federal de Juiz de Fora (UFJF), Campus Universitário, Bairro Martelos, 36036-900 Juiz de Fora, MG, Brasil \\ ${ }^{2}$ Faculdade de Farmácia, Núcleo de Identificação e Quantificação Analítica, \\ Universidade Federal de Juiz de Fora (UFJF), Campus Universitário, Bairro Martelos, 36036-900 Juiz de Fora, MG, Brasil \\ ${ }^{3}$ Instituto de Ciências Biológicas, Departamento de Biologia, Laboratório de Genética, \\ Universidade Federal de Juiz de Fora (UFJF), Campus Universitário, Bairro Martelos, 36036-900 Juiz de Fora, MG, Brasil
}

Manuscript received on February 24, 2011; accepted for publication on May 16, 2011

\begin{abstract}
This work describes an efficient micropropagation protocol for Verbena litoralis and the study of the antinociceptive and antioxidant activities in extracts of this species. For the establishment in vitro, surfacesterilization procedures and PVPP showed high efficiency in fungal-bacterial contamination and phenol oxidation controls. Nodal segments cultivation in MS medium supplemented with 6-benzyladenine $(7.5 \mu \mathrm{M}) / \alpha$-naphthaleneacetic acid (NAA; $0.005 \mu \mathrm{M})$ induced multiple shoots. Elongated shoots were rooted with IAA $(0.2 \mu \mathrm{M})$. Acclimatization rates were elevated and the plants showed the typical features of this species. The hexanic fraction (HF) of powdered leaves presented a radical scavenging activity with $\mathrm{IC}_{50}=169.3 \mu \mathrm{g} \mathrm{mL}{ }^{-1}$. HF showed a non-dose dependent analgesic activity in the writhing test; its antinociceptive activity in the hot plate test was restricted to $500 \mathrm{mg} \mathrm{kg}^{-1}$, which is the highest dose. The results of this study showed the potential of tissue culture on conservation and large scale multiplication and confirmed the traditional folk medicine use of $V$. litoralis.
\end{abstract}

Key words: tissue culture, biodiversity conservation, biological effects, natural products.

\section{INTRODUCTION}

Verbenaceae is found in practically all terrestrial ecosystems. It is one of the five most important families among the Eudicots of Brazilian Campos Rupestres (Giulietti et al. 1987). This family includes 1035 species and 36 genera with a pantropical

Correspondence to: Paulo Henrique Pereira Peixoto

E-mail: paulo.peixoto@ufjf.edu.br distribution. Few species are found in temperate areas (Atkins 2004). In Brazil, the most important specific diversity centers are located at Cadeia do Espinhaço, Minas Gerais State, and at Chapada Diamantina, Bahia State (Salimena-Pires and Giulietti 1998).

Plant tissue culture techniques have been widely applied to medicinal and aromatic plants (Jain and Saxena 2009), and in vitro propagation appears as an 
alternative to conventional vegetative propagation and germplasm conservation, especially for endemic and endangered species (Passera and Ambrosetti 1999, Gupta et al. 2001, Peixoto et al. 2006).

Several Verbenaceae genera have being investigated due to their medicinal properties (Pascual et al. 2001, Costa et al. 2003, Penido et al. 2006, Saini et al. 2007). Verbena litoralis Kunth is currently used in traditional South and Central American folk medicine against diarrhea, fever, gastrointestinal disorders and some sexually transmitted diseases (Pérez-Arbeláez 1978, Ocampo and Maffioli 1987). Preliminary ethnobotanical and phytochemical information on $V$. litoralis has been published and various constituents were obtained (Umaña and Castro 1990a, b, Li et al. 2001a, b). The interest in this plant increased after the isolation of substances with nerve growth factor-potentiating activity (Li et al. 2001a, b, 2003a, b, c). The aerial parts of this plant produce an extract that revealed an interesting preliminary antibacterial potential (Castro-Gamboa and Castro 2004).

As the use of analgesic agents is somewhat criticized for its adverse side effects, induced tolerance and dependence, new analgesic drugs lacking these effects are being searched for all over the world (Dharmasiri et al. 2003). Further studies should be conducted with plants used in folk medicine since they have a low-cost and can be an effective alternative to the opiates currently used. Several studies have been carried out with $V$. litoralis due to the isolation of neuritogenically active substances, such as verbenachalcone ( $\mathrm{Li}$ et al. 2001a), littoralisone ( $\mathrm{Li}$ et al. 2001b) and littorachalcone (Li et al. 2003a). Moreover, CastroGamboa and Castro (2004) managed to isolate two new iridoids, $6 S$-hydroxy- $8 S$-methyl-4-methylenehexahydro-cyclopenta[c]pyran-3-one and $6 S, 9 S$ dihydroxy-8S-methyl-4-methylene-hexahydrocyclopenta $[c]$ pyran-3-one, which showed moderate antibacterial, intestinal peristaltic reflex and antioxidant activities.
The aim of this work was to develop a large scale micropropagation method and investigate the effectiveness of the antinociceptive and antioxidant activities of $V$. litoralis extracts.

\section{MATERIALS AND METHODS}

\section{IN VITRO PLANT MATERIAL}

Verbena litoralis Kunth plants were collected at Cadeia do Espinhaço, Minas Gerais State, and in Southeastern Brazil. The plants were further established by vegetative propagation and grown in an orchard at the Experimental Plant Station at the Universidade Federal de Juiz de Fora, Juiz de Fora, Minas Gerais State, Brazil. The donor plants were sprayed once a week with a Benomyl solution $\left(0.172 \mathrm{mg} \mathrm{L}^{-1}\right.$; DuPont ${ }^{\circledR}$, USA). Then, apical cuttings (2-3 cm height) with two to three axillary buds were removed from shrubs and the explants were washed in running tap water for $60 \mathrm{~min}$, followed by immersion in ethanol $70 \%(\mathrm{v} / \mathrm{v})$ for $30 \mathrm{~s}$ and with Benomyl solution $\left(0.172 \mathrm{mg} \mathrm{L}^{-1}\right)$ for $10 \mathrm{~min}$. The explants were soaked in $100 \mathrm{~mL}$ of a commercial bleach (2\% active chlorine) $40 \%(\mathrm{v} / \mathrm{v})$ solution added two drops $(30 \mu \mathrm{L})$ of Tween-20 (Sigma ${ }^{\circledR}$, USA) for $15 \mathrm{~min}$, and finally rinsed five times in sterile distilled water. The explants were cultivated on a half-strength MS basal medium (Murashige and Skoog 1962) supplemented with sucrose (30 $\mathrm{g} \mathrm{L}^{-1}$; Vetec, Brazil), myo-inositol (100 mg L ${ }^{-1}$; Sigma ${ }^{\circledR}$ ), vitamins (nicotinic acid, pyridoxine- $\mathrm{HCl}$ and thiamin- $\mathrm{HCl}$; all at $0.05 \mathrm{mg}$ $\mathrm{L}^{-1}$; Sigma $\left.{ }^{\circledR}\right)$, glycine $\left(0.05 \mathrm{mg} \mathrm{L}^{-1}\right.$; Sigma $\left.{ }^{\circledR}\right)$ and Benomyl $\left(0.172 \mathrm{mg} \mathrm{L}^{-1}\right)$.

Attempting phenol oxidation control, polyN-vinylpyrrolidone (PVPP; 0.5 g L $^{-1}$; Sigma ${ }^{\circledR}$ ) was included in a media culture. Phenol oxidation measurement was accessed by complete browning of nodal explants. All media were prepared with $7 \mathrm{~g} \mathrm{~L}^{-1}$ agar $\left(\right.$ Sigma $\left.^{\circledR}\right)$ and the $\mathrm{pH}$ of the media was adjusted to 5.7 before autoclaving at $120^{\circ} \mathrm{C}$, at $1 \mathrm{~atm}$ for $20 \mathrm{~min}$. The excision of the explants was 
carried out under sterile conditions in a laminar flow hood $\left(\mathrm{VECO}^{\circledR}\right.$, Brazil). The cultures were incubated in a growing room at $25-28^{\circ} \mathrm{C}$ under a 16-h photoperiod and photon flux density of $35 \mu \mathrm{mol} \mathrm{m} \mathrm{m}^{-2} \mathrm{~s}^{-1}$ provided by cool-white fluorescent tubes ( $20 \mathrm{~W}$, Osram Sylvania Inc.). A single in vitro plantlet was used as the initial source of explants for subsequent experiments. Experiments were set up in a completely randomized design with 15 test tubes $(25 \times 150 \mathrm{~mm})$ containing one explant per test tube per treatment.

\section{SHOOT PROLIFERATION AND ROOTING}

Full-strength MS-based medium supplemented with sucrose (30 $\left.\mathrm{g} \mathrm{L}^{-1}\right)$, myo-inositol $\left(100 \mathrm{mg} \mathrm{L}^{-1}\right)$, vitamins (nicotinic acid, pyridoxine- $\mathrm{HCl}$ and thiamin- $\mathrm{HCl}$; all at $0.05 \mathrm{mg} \mathrm{L}^{-1}$ ) and glycine (0.05 mg L $\left.^{-1}\right)$ induced shoot proliferation from apical nodal segment cuttings with combinations of 6-benzyladenine (BA; 0, 2.5, 5.0 or $7.5 \mu \mathrm{M}$ ) and $\alpha$-naphthaleneacetic acid (NAA; 0, 0.005, 0.05 or $0.5 \mu \mathrm{M})$ in a completely randomized design. Elongated apical shoots (average 2-cm height) from MS-based medium (without growth regulators) were rooted in a full-strength MS-based medium supplemented with sucrose $\left(30 \mathrm{~g} \mathrm{~L}^{-1}\right)$, myo-inositol (100 mg L $\mathrm{m}^{-1}$ ), vitamins (nicotinic acid, pyridoxine$\mathrm{HCl}$ and thiamin- $\mathrm{HCl}$; all at $0.05 \mathrm{mg} \mathrm{L}^{-1}$ ) and glycine (0.05 $\left.\mathrm{mg} \mathrm{L}^{-1}\right)$ added with either NAA, indole-3acetic acid (IAA) or indole-3-butyric acid (IBA) at $0,0.1,0.2,0.3$ or $0.4 \mu \mathrm{M}$. All growth regulators were added before the autoclaving of the culture media. Evaluated parameters were the number of shoots, elongated shoots, callus formation, percentage of root induction, and roots length $45 \mathrm{~d}$ after culture initiation. The number of shoots and roots was normalized through the equation $(\sqrt{\chi+0.5})$. The length of roots and shoots was normalized through the equation $\log (\mathrm{x}+1)$. The data were subjected to one-way analysis of variance (ANOVA) and Tukey and Scott-Knott multiple range tests. Statistical analyses were carried out using the Statistical Package for Social Sciences (SPSS) v.8.0 for Windows software.

\section{ACCLIMATIZATION}

Elongated rooted plants (average 5-cm height) from rooting medium supplemented with $0.2 \mathrm{mM}$ IAA were individually transferred to plastic beakers (100-mL capacity) containing $25-30 \mathrm{~mL}$ of sterile distilled water, covered with a transparent plastic bag and kept for 2 days under the same growth room conditions. Then, the plants were transferred to plastic containers filled with horticulture organic substrate (Plantmax ${ }^{\circledR}$, Paulínia, Brazil), soil and sand $(2: 2: 1)$ under a shading house $(50 \%$ light interception). Plastic bags were progressively opened by lateral cuts throughout the first 3 weeks of the hardening-off process. At the end of the fourth week, the containers were completely uncovered. Plants were irrigated on a daily basis up to the third week, and at every $2 \mathrm{~d}$ during the fourth week. After 2 months in the greenhouse, plants were successfully transferred to beds containing a mixture soil:sand:manure in the ratio 4:3:1 (v/v/v). The plants were irrigated twice a week.

\section{ANTINOCICEPTIVE AND ANTIOXIDANT ACTIVITIES}

Dried powdered leaves (50 g) of $V$. litoralis were macerated at room temperature. The dry powder was Soxhlet partitioned with hexane and yielded $0.7 \mathrm{~g}$ of hexanic fraction (HF). Only one fraction was prepared due to the small amount of material available. The choice was made to work with HF because previous studies reported that the most found activities are concentrated in the non-polar extracts (Li et al. 2003a, b).

RADICAL SCAVENGING ACTIVITY

The radical scavenging activity of DPPH (2,2-difenil-1,2-picrilhidrazil) was determined according to Sreejavan and Rao (1997) with a few 
modifications. $1.5 \mathrm{~mL}$ of ethanolic $(\mathrm{EtOH})$ solution of DPPH (0.05 mM) (Jagetia et al. 2003) was added to a $500 \mu \mathrm{L}$ EtOH solution of $\mathrm{HF}$ in the following concentrations: $250 ; 125 ; 62.50 ; 31.25 ; 15.62 ; 7.81$; $3.90 ; 1.95 ; 0.97 \mu \mathrm{g} \mathrm{mL}^{-1}$. A $30 \mathrm{~min}$ reaction was allowed to happen in the dark at room temperature, after which the absorbance was monitored spectrophotometrically at $517 \mathrm{~nm}$. A blank was used to ignore the influence of the color in the samples. An EtOH solution of DPPH $0.05 \mathrm{mM}$ was used as negative control. Vitamin $\mathrm{C}$ was used as standard in the same concentrations. The reduction percentage of the DPPH absorbance gave the DPPH scavenging activity of the test samples and was used as a marker for their antioxidant activities. The $\mathrm{IC}_{50}$ was given by the equation $\mathrm{IC}_{50}$ $(\%)=100 \times\left(A_{0}-A_{s}\right) / A_{0}$, where $A_{0}$ and $A_{s}$ stand for the absorbance of the negative control and the absorbance of the sample, respectively. Tests were carried out in triplicate.

\section{ANTINOCICEPTIVE ACTIVITY}

Male Swiss mice (Mus musculus) (25-30g) from the Center of Reproductive Biology at the Universidade Federal de Juiz de Fora - UFJF - (Juiz de Fora, Minas Gerais State, Brazil) were used throughout the experiments. They were housed in a standard, room temperature cage under environmental conditions and fed with a rodent diet. This study was conducted in accordance with guidelines set forth by the Brazilian Association for Laboratory Animal Science (COBEA) and has been approved by the Research Commission for Ethics and Animal Experimentation of UFJF.

\section{Writhing ANd Hot Plate Tests}

For all tests described below, HF was solved in saline solution of $1 \%$ DMSO:Tween $80(1: 2, \mathrm{v} / \mathrm{v})$. Writhing activity in mice was evaluated according to Koster et al. (1959). Eight $(\mathrm{n}=8)$ animals were induced in each of the five groups (standard, control and HF: $100 \mathrm{mg} \mathrm{kg}^{-1}, 300 \mathrm{mg} \mathrm{kg}^{-1}$ and $500 \mathrm{mg} \mathrm{kg}^{-1}$ ). The different concentrations of HF were orally administered. One hour later, $1.0 \mathrm{~mL}$ of $0.6 \%$ acetic acid was injected intraperitoneally. The number of writhes/mouse was counted during a $20 \mathrm{~min}$ period, starting $10 \mathrm{~min}$ after the administration of the acetic acid. Indometacin $5 \mathrm{mg} \mathrm{kg}^{-1}$ and saline solution of 1\% DMSO: Tween $80(1: 2, \mathrm{v} / \mathrm{v})$ were respectively used as standard and control, and were also orally administered $\left(0.3 \mathrm{~mL}\right.$ animal $\left.^{-1}\right)$ one hour before the administration of the acetic acid.

The hot plate test was performed according to Franzotti et al. (2000), with a few modifications. Ten animals $(n=10)$ were included in each of the six groups (standard, control and HF: $100 \mathrm{mg} \mathrm{kg}^{-1}$, $300 \mathrm{mg} \mathrm{kg}^{-1}$ and $500 \mathrm{mg} \mathrm{kg}^{-1}$ ). Animals were placed on a hot-plate set at $55 \pm 0.5^{\circ} \mathrm{C}$. Reaction time was recorded at different times after the different concentrations of $\mathrm{HF}$ had been administered (30, 60, 90 and $120 \mathrm{~min}$.), when the animals licked their fore and hind paws or jumped. Animals that did not react after $30 \mathrm{~s}$ were taken off the plate to avoid damage to tissues, which could jeopardize further evaluations. A baseline was obtained immediately before the drug administration and was defined as a normal reaction of the animal to temperature increase. The control group was orally administered with $0.3 \mathrm{~mL} / 30 \mathrm{~g}$ of saline solution of $1 \%$ DMSO:Tween $80(1: 2, \mathrm{v} / \mathrm{v})$. In the standard group, morphine $5 \mathrm{mg} \mathrm{Kg}^{-1}$ was administered subcutaneously (Kuraishi et al. 1983).

The data of antinociceptive and antioxidant activities are presented as the means \pm S.E.M. for eight animals per group in writhing test and ten animals per group for the hot plate assay. One-way ANOVA was used to compare means followed by Bonferroni's test when appropriate. Values of $p<0.05$ were considered to be statistically significant. Statistical analyses were carried out using the Statistical Package for Social Sciences (SPSS) v.8.0 for Windows software. 


\section{RESULTS AND DISCUSSION}

\section{TISSUE CULTURE INITIATION}

As previously found for explants of L. filifolia (Peixoto et al. 2006), PVPP showed an effectiveness on phenol oxidation control during the in vitro establishment of apical microcuttings, reducing the number of brownish explants. The percentage of explants oxidized was less than $1 \%$. Disinfection procedures showed high efficiency in the control of the fungal and bacterial contamination. The use of benomyl, ethanol and commercial bleach in the disinfection produced more than $95 \%$ of the free bacterial and fungal cultures during the in vitro establishment of apical cuttings.

\section{SHOOT PROLIFERATION}

After the establishment phase, different concentrations of plant growth regulators enabled the plant propagation via nodal segments, which were placed vertically on a surface of a solidified culture medium. BA and NAA interaction showed statistical differences for the number of shoots (Table I and Figure 1-AB) and roots (Table II and Figure 1-AB) produced in response to the increase of BA in the culture medium. For $V$. litoralis, the highest multiple shoot response was obtained after the treatment with BA $(7.5 \mu \mathrm{M}) /$ NAA $(0.005 \mu \mathrm{M}$; Table I), whereas in L. filifolia multiple shoots were observed with BA $(4.5 \mu \mathrm{M}) / \mathrm{NAA}$ $(0.005 \mu \mathrm{M})$ (Peixoto et al. 2006). BA combined with NAA produced a maximum of 4.8 shoots per explant (Table I), while NAA alone reduced the number of shoots, reinforcing the importance of cytokinins for shoot induction in $V$. litoralis. For $L$. alba, the addition of $0.23 \mu \mathrm{M}$ IAA to MS medium significantly decreased plant regeneration, number of shoots per explant and number of nodes per plantlet, as compared to MS medium lacking growth regulators (Tavares et al. 2004). In general, higher rates of multiplication were observed in the presence of higher concentrations of BA (Table I). Similar results were observed for Lippia junelliana (Juliani et al. 1999), L. alba (Gupta et al. 2001) and L. filifolia (Peixoto et al. 2006).

TABLE I

Average shoot numbers of Verbena litoralis as affected by BA and NAA combinations, $45 \mathrm{~d}$ after in vitro culture.

\begin{tabular}{c|c|c|c|c|c}
\hline \multirow{2}{*}{$\mathrm{BA}(\mu \mathrm{M})$} & \multicolumn{5}{|c}{ NAA $(\mu \mathrm{M})$} \\
\cline { 2 - 6 } & 0 & 0.005 & 0.05 & 0.5 & \\
\hline 0 & $1.57 \mathrm{a}^{1}$ & $1.28 \mathrm{a}$ & $1.09 \mathrm{a}$ & $2.78 \mathrm{a}$ & $1.68 \mathrm{~B}$ \\
\hline 2.5 & $2.53 \mathrm{a}$ & $1.37 \mathrm{ab}$ & $0.74 \mathrm{~b}$ & $0.62 \mathrm{~b}$ & $1.32 \mathrm{~B}$ \\
\hline 5.0 & $2.09 \mathrm{a}$ & $2.31 \mathrm{a}$ & $2.46 \mathrm{a}$ & $1.25 \mathrm{~b}$ & $2.03 \mathrm{~B}$ \\
\hline 7.5 & $4.62 \mathrm{a}$ & $4.82 \mathrm{a}$ & $3.39 \mathrm{a}$ & $1.38 \mathrm{~b}$ & $3.55 \mathrm{~A}$ \\
\hline
\end{tabular}

${ }^{1}$ Means followed by the same small letters (in each line; for NAA doses) and capital letters (in last row; for BA doses) are not different according to Tukey's test at $5 \%$ of probability.

TABLE II

Average root numbers of Verbena litoralis as affected by BA and NAA combinations, $45 \mathrm{~d}$ after in vitro culture.

\begin{tabular}{c|c|c|c|c|c}
\hline \multirow{2}{*}{$\mathrm{BA}(\mu \mathrm{M})$} & \multicolumn{5}{|c}{$\mathrm{NAA}(\mu \mathrm{M})$} \\
\cline { 2 - 6 } & 0 & 0.005 & 0.05 & 0.5 & \\
\hline 0 & $4.3 \mathrm{a}^{1}$ & $4.1 \mathrm{a}$ & $8.5 \mathrm{a}$ & $4.5 \mathrm{a}$ & $5.4 \mathrm{~A}$ \\
\hline 2.5 & $2.5 \mathrm{a}$ & $3.2 \mathrm{ab}$ & $3.7 \mathrm{~b}$ & $6.8 \mathrm{~b}$ & $4.1 \mathrm{~A}$ \\
\hline 5.0 & $0 \mathrm{a}$ & $0 \mathrm{a}$ & $0 \mathrm{a}$ & $0 \mathrm{~b}$ & $0 \mathrm{~B}$ \\
\hline 7.5 & $0 \mathrm{a}$ & $0 \mathrm{a}$ & $0 \mathrm{a}$ & $0 \mathrm{~b}$ & $0 \mathrm{~B}$ \\
\hline
\end{tabular}

${ }^{1}$ Means followed by the same small letters (in each line; for NAA doses) and capital letters (in last row; for BA doses) are not different according to Tukey's test at $5 \%$ of probability.

During our experiments, we do not observed hyperhydricity, a negative effect commonly observed after BA treatment (Phan and Hegedus 1986). In this assay, rooting was observed. In MS media and in the small concentration of BA, $100 \%$ of explants showed rooting (Figure 1-A). At higher concentrations of BA, no rooting was observed even when NAA was included in the culture media 
(Table II and Figure 1-B). Although not being important at this stage, rooting can increase the efficiency of the propagation process, since it reduces the time for reintroducing the plants under field conditions.

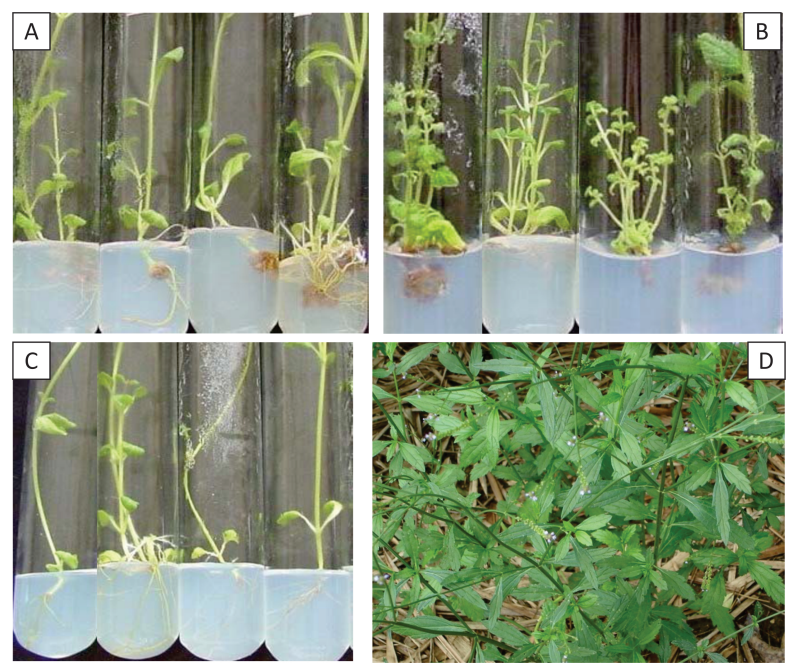

Fig. 1 - (A and B) Multiple rooting and shooting responses of Verbena litoralis nodal segments, $45 \mathrm{~d}$ after in vitro culture. Treatments $(\mu \mathrm{M})$ : A) BA 2.5 X NAA 0; BA 2.5 X NAA 0.005; BA $2.5 X$ NAA 0.05 ; BA $2.5 X$ NAA 0.5 ; B) BA $7.5 X$ NAA 0 BA 7.5 X NAA 0.005 ; BA 7.5 X NAA 0.05 ; BA 7.5 X NAA 0.5 (C) Rhiozogenic responses of elongated shoots of $\mathrm{V}$. litoralis, 45 days after inoculation. Treatments $(\mu \mathrm{M})$ : Control; IAA 0.2; IAA 0.3; IAA 0.4. (D) Acclimatized plants of $V$. litoralis.

\section{ROOTING AND ACCLIMATIZATION}

Shoots of $V$. litoralis rooted under all auxin treatments and in the control (Figure 1-C), as found for L. alba (Gupta et al. 2001) and L. filifolia (Peixoto et al. 2006). The best root system was observed in the presence of IAA at $0.2 \mu \mathrm{M}$, with nearly 11 roots per explant (Table III). This IAA concentration did not induce callus formation at shoots basis, which is a positive effect, since callus formation acts as a mechanical barrier to nutrient and water uptake (Thorpe et al. 1991, De Klerk 2002). IAA also induced the high shoot length production, although the length of the shoots was not an important factor for plant survival during the hardening-off phase. The roots length did not differ significantly among the different treatments (data not shown).
TABLE III

Average root numbers in elongated shoot of Verbena litoralis as affected by NAA, IAA and IBA, $45 \mathrm{~d}$ after in vitro culture.

\begin{tabular}{c|c|c|c}
\hline \multirow{2}{*}{$\begin{array}{c}\text { Concentration } \\
(\mu \mathrm{M})\end{array}$} & NAA & IAA & IBA \\
\cline { 2 - 4 } & $2.8 \mathrm{e}^{1}$ & $2.8 \mathrm{e}$ & $2.8 \mathrm{e}$ \\
\hline 0 & $6.5 \mathrm{c}$ & $5.8 \mathrm{c}$ & $6.3 \mathrm{c}$ \\
\hline 0.1 & $6.8 \mathrm{~b}$ & $10.8 \mathrm{a}$ & $7.8 \mathrm{~b}$ \\
\hline 0.2 & $7.5 \mathrm{~b}$ & $8.5 \mathrm{a}$ & $8.1 \mathrm{a}$ \\
\hline 0.3 & $4.8 \mathrm{~d}$ & $9.0 \mathrm{a}$ & $7.0 \mathrm{~b}$ \\
\hline 0.4 & & &
\end{tabular}

${ }^{1}$ Means followed by the same letters are not different according to Scott-Knott's test at $5 \%$ of probability.

Plant survival rates were as high as $96 \%$ of the 128 acclimatized plants that were transferred to ex vitro conditions. The plants grew normally, and set flowers. Acclimatized plants displayed the typical features of this species (Figure 1-D).

\section{ANTIOXIDANT ACTIVITY}

The radical scavenging activity of the compounds can be measured as a decolorizing effect following the trapping of the unpaired electrons of DPPH. The lower value of $\mathrm{IC}_{50}$ indicates a higher antioxidant activity. The $\mathrm{HF}$ and vitamin $\mathrm{C}$ demonstrated a scavenging activity of $\mathrm{DPPH}$ radicals with $\mathrm{IC}_{50}$ values of $169.3 \mu \mathrm{g} \mathrm{mL}-1$ and $2.5 \mu \mathrm{g} \mathrm{mL}{ }^{-1}$, respectively. The antioxidant activity of $\mathrm{FH}$ from $V$. litoralis was lower than that found by Mensor et al. (2001), which can be attributed to different sources of plant material and also to the time to collect leaves in the field.

\section{ANTINOCICEPTIVE ACTIVITY}

In the abdominal writhing model the acetic acid addition is thought to cause inflammation due to the increase in the levels of cytokines, prostaglandins and bradykinins, and other endogenous substances that stimulate nociceptive endings (Pini et al. 1996). The HF $100 \mathrm{mg} \mathrm{kg}^{-1}, 300 \mathrm{mg} \mathrm{kg}^{-1}$ and $500 \mathrm{mg} \mathrm{kg}^{-1}$, 
respectively, showed an average inhibition percentage of $52.6 \%, 52.6 \%$, and $56.9 \%$, therefore suggesting a good antinociceptive potential. Nevertheless, a significant dose-dependent relation could not be established (Figure 2). Indometacin, used as a standard, showed $76.22 \%$ of inhibition.

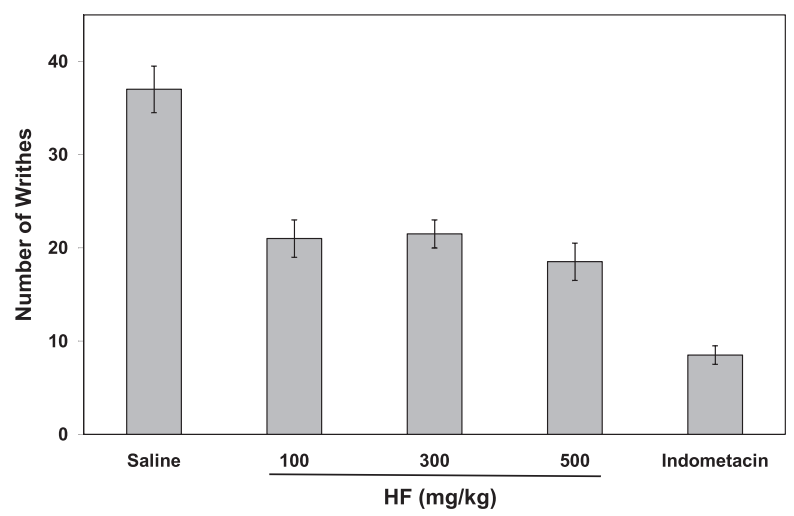

Fig. 2 - Analgesic effect of HF on the writhing response induced by acetic acid $0.6 \%$ in mice. Indometacin $5 \mathrm{mg} \mathrm{kg}^{-1}$ was used as standard. (Data expressed as mean \pm S.E.M. $\mathrm{n}=8$ mice/group; ANOVA; Bonferroni's test)

Considering the fact that the writhing model involves several nociceptive mechanisms, such as amines release, related to the sympathetic system, and endogenous substances related to inflammation, the hot plate essay is important to exclusively evaluate the central analgesic effect of HF (Pini et al. 1996). In the hot plate test a significant difference from the saline control was found only for $500 \mathrm{mg} \mathrm{kg}^{-1}$, therefore limiting the potential supra-spinal analgesic activity to a higher dose. Morphine reached its peak of action at $60 \mathrm{~min}$ and HF $500 \mathrm{mg} \mathrm{kg}^{-1}$ showed its maximum potential activity 90 min after oral administration (Figure 3).

The difference between the results found by the hot plate and writhing test may be related to the gastroprotective effects and antioxidant activity of compounds of $V$. litoralis reported by CastroGamboa and Castro (2004), and the correlation between antioxidant and anti-inflammatory activities (Wang et al. 2004). Unlike the hot plate

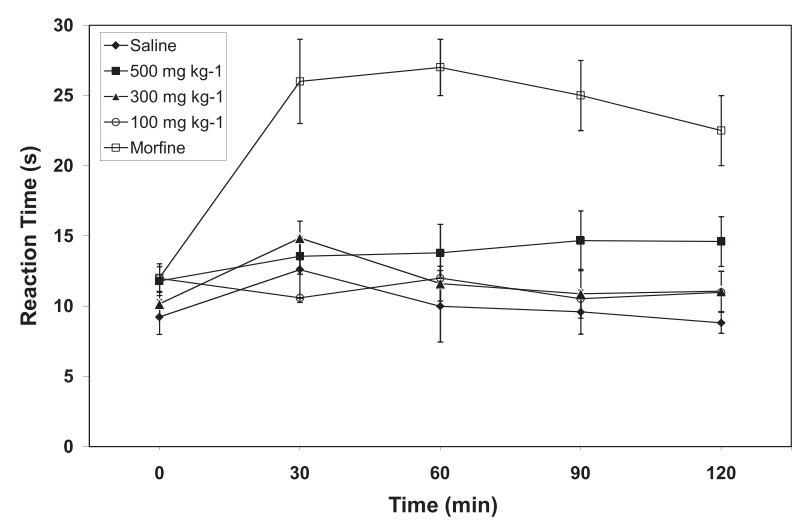

Fig. 3 - Analgesic effect $\left(\mathrm{mg} \mathrm{Kg}^{-1}\right)$ of HF on the Hot Plate test. O time $=$ baseline (Data expressed as mean \pm S.E.M. $\mathrm{n}=10$ mice/group; ANOVA; Bonferroni's test).

test, which is restricted to spinal nociception, the writhing test response can be affected by other processes involved. The administration of acetic acid addition in the writhing test induces inflammation, which leads to gastric irritation, bleeding and gastric mucosa damage (Andrade et al. 2007). Therefore, we suggest that anti-inflammatory and antinociceptive activities are acting together in the writhing test in order to reduce its response. These results may indicate potential anti-inflammatory activity of HF, which is already being tested. As the $\mathrm{HF}$ of $V$. litoralis produced a significant decrease in the number of writings in the antinociceptive essay and had some antioxidant effects, the traditional use in folk medicine was confirmed. HF analgesic activity can be increased by its potential antiinflammatory activity.

The results of this study showed the potential importance of tissue culture on a large scale multiplication and conservation, and confirmed the traditional use of $V$. litoralis in folk medicine.

\section{ACKNOWLEDGMENTS}

We thank Ana Cristina Alves Atala for helping us in preparing the figures and the Fundação de Amparo à Pesquisa do Estado de Minas Gerais (FAPEMIG) and Universidade Federal de Juiz de Fora (UFJF) for the financial support. 


\section{RESUMO}

Este trabalho descreve um protocolo eficiente de micropropagação para Verbena litoralis e estuda as atividades antinociceptiva e antioxidante de extratos desta espécie. Para o estabelecimento in vitro, os procedimentos de desinfecção e o PVPP mostraram alta eficiência no controle da contaminação por fungos e bactérias e da oxidação fenólica. O cultivo de segmentos nodais em meio MS suplementado com 6-benziladenina $(7,5 \mu \mathrm{M})$ e ácido $\alpha$-naftalenoacético (ANA; 0,005 $\mu \mathrm{M}$ ) induziu múltiplos brotos. Brotos alongados foram enraizados com AIA $(0,2 \mu \mathrm{M})$. As taxas de aclimatização foram elevadas e as plantas apresentaram características típicas da espécie. A fração hexânica $(\mathrm{FH})$ de folhas trituradas apresentou atividade sequestradora de radicais livres com $\mathrm{IC}_{50}=169,3 \mu \mathrm{g} \mathrm{mL} \mathrm{L}^{-1}$. A FH mostrou atividade analgésica não dose-dependente no teste das contorções abdominais; sua atividade antinociceptiva no teste de placa quente foi restrita a $500 \mathrm{mg} \mathrm{kg}^{-1}$, a dose mais elevada. Os resultados deste estudo mostraram o potencial da cultura de tecidos na conservação e multiplicação em larga escala de $V$. litoralis e confirmaram o uso tradicional dessa planta na medicina popular.

Palavras-chave: cultura de tecidos, conservação da biodiversidade, efeitos biológicos, produtos naturais.

\section{REFERENCES}

Andrade SF, CARdoso LGV, CARVAlHo JCT AND Bastos JK. 2007. Anti-inflammatory and antinociceptive activities of extract, fractions and populnoic add from bark wood of Austroplenckia populnea. J Ethnopharmacol 109: 464-471.

AtKINS S. 2004. Verbenaceae. In: KUBTZKI K AND KADEREIT JW (Eds), The families and genera of vascular plants, v. 7, Berlin: Springer-Verlag, Berlin, p. 449-468.

CAStro-Gamboa I AND CASTRO O. 2004. Iridoids from the aerial parts of Verbena litoralis (Verbenaceae). Phytochem 65: 2369-2372.

Costa VB, Coube CS, Marinho BG, Matheus Me, Leitão SG AND FERNANDES PD. 2003. Anti-inflammatory and analgesic activity of Bouchea fluminensis. Fitoterapia 74: $364-371$.

DE KLERK GJ. 2002. Rooting of microcuttings: theory and practice. In Vitro Cell Dev Biol Plant 38: 415-422.
DHARMASIRI MG, JAYAKODY JRAC, GALHENA G, LIYANAGE SSP AND RABIASOORIYA WD. 2003. Anti-inflammatory and analgesic activities of mature fresh leaves of Vitex negundo. J Ethnopharmacol 87: 199-206.

FRANZOTTI EM, SANTOS CV, RODRIGUES HM, MOURÃO RH, ANDRADE MR AND ANTONIOLli AR. 2000. Antiinflammatory, analgesic activity and acute toxicity of Sida cordifolia L. (Malva-branca). J Ethnopharmacol 72: 273-277.

Giulietti AM, Menezes NL, Pirani JR, Meguro M AND WANDERLEy MGL. 1987. Flora da Serra do Cipó, Minas Gerais: Caracterização e Lista das Espécies. Bol Bot Univ São Paulo 9: 1-151.

GuPTA SK, KhanUJa SPS AND KUMAR S. 2001. In vitro micropropagation of Lippia alba. Curr Sci 81: 206-210.

JAGETIA GC, VENKATESHA VAAND REDDYTK. 2003. Naringin, a citrus flavonone, protects against radiation-induced chromosome damage in mouse bone marrow. Mutagenesis 18: 337-343.

JAIN SM AND SAXENA PK. 2009. Protocols for in vitro cultures and secondary metabolite analysis of aromatic and medicinal plants. New York: Humana Press, New York, USA, $350 \mathrm{p}$.

JULIANI JR HR, KOROCH AR, JULIANI HR AND TRIPPI VS. 1999. Micropropagation of Lippia junelliana (Mold.) Tronc. Plant Cell Tiss Organ Cult 59: 175-179.

Koster R, Anderson M AND DE Debeer EJ. 1959. Acetic acid for analgesic screening. Fed Proc 18: 412.

KURAishi Y, HARADA Y, ARATANI S, SATOH M AND TAKAGI H. 1983. Involvement of the spinal noradrenergic and serotonergic systems in morphine analgesia: the differences in mechanical and thermal analgesic tests. Brain Res 273: 245-252.

LI Y, ISHIBASHI M, CHEN X AND OHIZUMI Y. 2003a. Littorachalcone, a new enhancer of NGF-mediated neurite outgrowth, from Verbena littoralis. Chem Pharm Bull 51: 872-874.

Li Y, Ishibashi M, Satake M, Chen X, Oshima Y and OHIZUMI Y. 2003b. Sterol and triterpenoid constituents of Verbena littoralis with NGF-potentiating activity. J Nat Prod 66: 696-698.

Li Y, IShibashi M, SATAKe M, CHEN X, OShima Y AND OHIZUMI Y. 2003c. A new iridoid glycoside with nerve growth factor-potentiating activity, gelsemiol 6'-transcaffeoyl-1-glucoside, from Verbena littoralis. Chem Pharm Bull 51: 1103-1105.

LI Y, MATSUNAGA K, ISHiBASHI M AND OHIZUMI Y. 2001b. Littoralisone a novel neuritogenic iridolactone having an unprecedented heptacyclic skeleton including four- and nine-membered rings consisting of glucose from Verbena littoralis. J Org Chem 66: 2165-2167.

Li Y, Matsunaga K, KATO R AND OHIZUMi Y. 2001a. Verbenachalcone, a novel dimeric dihydrochalcone with potentiating activity on nerve growth factor-action from Verbena littoralis. J Nat Prod 64: 806-808. 
Mensor LL, Menezes FS, Leitão GG, Reis AS, SANTos TC, COUBE CS AND LEITÃo SG. 2001. Screening of Brazilian plant extracts for antioxidant activity by the Use of DPPH free radical method. Phytother. Res 15: 127-130.

Murashige T AND Skoog F. 1962. A revised media for rapid growth and bioassays with tobacco tissue cultures. Physiol Plant 15: 473-497.

OCAMPO RA AND MAFFIOLI A. 1987. El uso de algunas plantas medicinales en Costa Rica, v. 1, $2^{\text {nd }}$ ed., San José: Litografia e Imprenta Lil, San José, Costa Rica, p. 79-81.

Pascual Me, Slowing K, Carretero E, Sánchez Mata D AND VILlar A. 2001. Lippia: traditional uses, chemistry and pharmacology: a review. J Ethnopharmacol 76: 201-214.

PASSERA CB AND AMBROSETTI JA. 1999. In vitro propagation of "incayuyo", Lippia integrifolia (Gris.) Hier. (Verbenaceae), a medicinal and aromatic plant of Monte Phytogeographical Province, Argentina. Acta Hort 502: 319-324.

Peixoto PhP, Salimena FRG, Santos MO, Garcia LS, PIERRE PMO, VicCINI LF AND OTONI WC. 2006. In vitro propagation of endangered Lippia filifolia Mart. and Schauer ex Schauer. In Vitro Cell Dev Biol Plant 42: 558-561.

Penido C, Costa KA, Futuro do, Paiva SR, Kaplan MAC, FigueIREDO MR AND HENRIQUES MGMO. 2006. Anti-inflammatory and anti-ulcerogenic properties of Stachytarpheta cayennensis (LC Rich) Vahl. J Ethnopharmacol 104: 225-233.

PÉrEZ-ArBElÁEZ E. 1978. Plantas útiles de Colombia, tercera redacción muy corregida y aumentada. Litografía Arco, $3^{\text {nd }}$ ed., Bogotá: Litografia Arco, Bogotá, Venezuela, 831 p.
Phan CT AND Hegedus P. 1986. Possible metabolic basis for the developmental anomaly called 'vitreous plants'. Plant Cell Tiss Organ Cult 6: 83-94.

Pini LA, SANDrini M AND VitAle G. 1996. The antinociceptive action of paracetamol is associated with changes in the serotonergic system in the rat brain. Eur $\mathrm{J}$ of Pharmacol 308: $31-40$.

SAINI N, Singh J, SEHGAL R AND OJHA S. 2007. Evaluation of liver function impairment and lipid peroxidation induced by Lantana camara leaf powder administration in adult rat serum and liver. Cell Mol Biol 53: 79-83.

SALIMENA-PIRES FR AND GIULIETTI AM. 1998. Flora da Serra do Cipó, Minas Gerais: Verbenaceae. Bol Bot Univ São Paulo 17: 155-180.

SREEJAVAN N AND RAO MNA. 1997. Free radical scavenging activity of curcuminoids. Drug Res 46: 169-171.

TAVAres ES, Lopes D, Bizzo HR, LAGE C AND LeITÃo SG. 2004. Kinetin enhanced linalool production by in vitro plantlets of Lippia alba. J Essent Oil Res 16: 405-408.

THORPE TA, HARRY IS AND KUMAR PP. 1991. Application of micropropagation to forestry. In: DEBERGH PC AND ZIMMERMAN RH (Eds), Micropropagation. Dordrecht: Kluwer Academic Publishers, Dordrecht, The Netherlands, p 311-316.

UMAÑA RE AND CASTRO O. 1990a. Chemical constituents of the aerial part of Verbena littoralis HBK. Quim Nova 13: 310-312.

UMAÑA RE AND CASTRO O. 1990b. Preliminar phytochemical study of Verbena littoralis HBK. Int J Crude Drug Res 2: 175-177.

WANG ZQ ET AL. 2004. A newly identified role for superoxide in inflammatory pain. J Pharmacol Exp Ther 309: 869-878. 